\title{
THE ESCAPING PRESENCE OF THE FEMALE IN THOMAS PYNCHON'S NOVELS
}

\author{
Carmen Pérez-Llantada Auría \\ University of Zaragoza (Spain)
}

\begin{abstract}
RESUMEN: Es el propósito de este artículo analizar la manera en la que Pynchon activa, de forma autoconsciente, un cuidadoso simbolismo en la figura femenina. Como focalizadoras socialmente comprometidas, los personajes femeninos se convierten en la herramienta narrativa del autor para llevar a cabo una dura crítica social y política de la América contemporánea. Al propio tiempo, una compleja galería de significantes femeninos con múltiples -o "derridianamente" diferidos-significados permite al novelista insistir en la imposibilidad epistemológica de alcanzar una representación satisfactoria de la realidad externa, abogando así por una reconceptualización del pensamiento clásico.
\end{abstract}

ABSTRACT: It is the main contention in this paper that Pynchon self-consciously activates a minutely-devised symbolism of the female figure. As socially-committed focalisers, female characters become Pynchon's narrative tools to carry on a harsh political and social criticism of contemporary America. On the other hand, through a complex gallery of metaphorical female signifiers with multiple -"deferred"significations, the post-modern novelist enquires into the epistemological impossibility of ever reaching a satisfactory representation of external reality, thus advocating a reconceptualization of classical thought.

Solid critical studies on Thomas Pynchon's narrative trajectory have extensively covered his fictional techniques (Cooper, 1983; Cowart, 1980; Seed, 1988; Tanner, 1979, 1982), his most recurrent narrative motifs (Bock \& Wertheim, 1986; Pearce, 1981; Plater, 1978), his satiric and moralistic vein (MacAdam, 1975; Newman, 1983), his postmodern condition and preoccupation for real history (McHale, 1979), his epistemological concerns (Hipkiss, 1984; Henkle, 1971; McConnell, 1977), or even interesting deconstructivist insights such as those of McHoul \& Wills (1990) or Solomon (1988). Highly-illuminating as well are those critical approaches (Clerc, 1982; Hoffman, 1979; Stonehill, 1988) that provide detailed analyses about the use of Pynchon's complex webs of metalanguages -mainly, those of science and technology, cinema, music, etc.- which self-consciously work as metaphorical constructs supporting deep significances within the narrative layout of his dense and difficult works. 
But these are only some instances, among many others, of interesting bibliographical sources which greatly help the Pynchonean reader to decipher the complexity of his literary productions. The avid readers of this author's enigmatic personality will surely agree that all his novels are built upon highly complicated frameworks made up of multifarious data that can hardly be interpreted in their totality because of their inherent excess of information.

Now that some years have passed since the publication of Mason \& Dixon, it may be time to make a retrospective analysis of Pynchon's narrative interest in the symbolic use of the escaping presence of the female. It is my main contention in this paper that the author activates all through his works a carefully-devised treatment of the female figure in order to carry on his harsh political and social criticism of contemporary America. Furthermore, through the use of female symbolism, the writer takes his readers to enquire into profound epistemological issues by making the ambiguous female character represent a signifier with multiple meanings, meanings that -in a deconstructivist parallelism- disperse rather than converge in an ultimate or absolute signification.

In Pynchon's first novel, one of the two protagonists, Stencil, searches for a mysterious woman called V., who gradually shifts from innocence and love to selfworship and automation. His search, however, is futile and, together with the reader, Stencil is lost in a labyrinth of multiple significations about the letter "v". From the very beginning of the story, this uncanny character can be understood either as a maternal symbol, or as the symbol of the Virgin, or of the Goddess Venus or -keeping in mind Henry Adams's (1900) intertext- as the symbol of the dynamo. Besides, all along the novel the reader comes across several references to legendary or mythical places such as Valletta, Vheissu or Venezuela, likewise echoing the ambiguous recurrence of this initial.

One of Stencil's first references to the mysterious V. appears in chapter 6, where the protagonist, referring to himself in the third person -as Henry Adams did in his Education - establishes a close relationship between V. and a real Armageddon, thus suggesting to the reader that we are clearly crossing the boundaries between fiction and real history:

[...] she'd been connected, though perhaps only tangentially, with one of those grand conspiracies or foretastes of Armageddon which seemed to have captivated all diplomatic sensibilities in the years preceding the Great War. V. and a conspiracy. Its particular shape governed only by the surface accidents of history at the time. (Pynchon, 1975: 155)

A few pages later the narrative voice insists on the ambiguity of the mysterious signifier when in free indirect style the reader finds a reference to the "Birth of Venus", the picture being contemplated by Signor Mantissa and Cessare at the end of 
chapter 8: "What sort of mistress, then, would Venus be? [...] What of her God, her void, her dreams? She was already a goddess" (p. 210), claims the narrator.

Significantly breaking with traditional narrative linearity, V.'s presence always implies, at the textual level, the appearance of disrupting of chronologic leaps. She/It first appears as Victoria Wren in El Cairo in 1898 and then in Florence. Later V. is a rat called Veronica. Then, she/it is the mistress of the engineer Kurt Mondaugen, this time appearing under the name of Vera Meroving at Foppl's party in Southeast Africa. After that she is seen disguised as the Bad Priest in Malt during the Second World War. It is particularly noticeable that the female impersonation of Vera Meroving shares a peculiar characteristic with some other females that appear in the novel as possibly related to the identity of V.. The feature we are referring to is a tendency towards inanimateness; in this case, Vera has an artificial eye which is minutely described in the novel as an intricate engineering device:

A bubble blown translucent, its "white" would show up when in the socket as a half-lit seagreen. A fine network of nearly microscopic fractures covered its surface. Inside were the delicately-wrought wheels, springs, ratchets of a watch, wound by a gold key which Fraülen Meroving wore on a slender chain round her neck. (p. 237)

Descriptive passages of similar characteristics are also found in chapter 14, entitled "V. in love", which is entirely devoted to V. and her fetishist relationship with Melanie L'Hermauit. Once again, a restrospective leap places the reader in Paris on the verge of the Great War, 1913. The narrative voice, in an attempt to insist on the mystery surrounding this female figure, asserts that even the reasons for their love relationship remain "a mystery to all observers" (p. 407). The very end of the chapter offers the reader an impressive portrayal of the complex electronic-wise nature of the mysterious V. at the age of seventy-three. The narrative voice -displaying a harsh social criticism on modern times- insists on the fact that V. has shifted into a product of the expanding technology "invading" us. It is the dominance of the inanimate over the human; a re-reading of Adams's metaphor of the Virgin and the dynamo:

[...] skin radiant with the bloom of some new plastic; both eyes glass but now containing photoelectric cells, connected by silver electrodes to optic nerves of purest copper wire and leading to a brain exquisitely wrought as a diode matrix could ever be. Solenoid relays would be her ganglia, servo-actuators move her flawless nylon limbs, hydraulic fluid be sent by a platinum heart-pump through butyrate veins and arteries. (p. 411)

Either readers accept, as Maijstral thinks, the "growing theory that V. was an obsession after all" (p. 448), or they may likewise recognize that V. is a personality disintegrating towards absolute inanimateness and thus that Stencil's is an endless quest after an ultimate signifier which forever escapes human physical perception. By 
the end of the novel the always-escaping signifier finally becomes Veronica Manganese in Valletta, in 1919. At this point, precisely, the puzzled reader should recall the narrator's words reminding us, with an unavoidable ironic undertone, that V. is just "a remarkably scattered concept" (p. 346).

Thomas Pynchon's second novel, The Crying of Lot 49 (1967) pertains to a parodic detectivesque genre, though this time the detective-protagonist is not a man but, significatively, a woman. In the very first pages of the novel, the reader is told that Oedipa Mass has been named executrix of the testament of her former lover Pierce Inverarity. The whole plot revolves about how the parodic female detective tries to find out whether she is the target of a postmortem hoax or whether there is such a thing as the Trystero postal system. In a deeper reading of the novel the reader may further conclude that Oedipa reifies a mythical quest for knowledge, with the clandestine postal system called Tristero and its fight against established social rules, playing the metaphoric role of the entropic forces that exist in a universe ruled by chaotics (Hayles, 1991).

While in search for an answer to the enigmatic lot 49, Oedipa's female focalisation also allows Thomas Pynchon to present his readers a painful vision of the social and political context of the 1960s in the U.S. In her journey across California, Oedipa and the reader become witnesses of the culture of the disinherited, and become trapped by the binary categorizations typical of Western representation: either rich or poor, system or paranoia, central or marginal, while gradually the female protagonist only becomes ascertained of her own marginal position.

Oedipa's physical and parodic quest also metaphorises the uncertainty inherent to Western knowledge once that causality and determinism are no longer accepted as ways of grasping external reality (Nadeau, 1981). "She had heard all about excluded middles; they were bad shit, to be avoided" (Pynchon, 1979: 125), says the narrative voice by the end of the novel. While trying to find a logical explanation for the Trystero, her representations of the events ironically rebel against her, and her logical inferences to solve the mystery of the postal system draw her into a labyrinth of uncertainty, of unconnected data, up to the point of feeling lost amidst a chain of signifiers devoid of absolute meanings. Earlier in the book Oedipa contemplated the mise-en-abyme painting by Remedios Varo "Bordando el manto terrestre", in which a group of girls, prisoners at the top of a tower -echoing the modernist tower of solipsism- embroider a kind of tapestry allegorically "seeking hopelessly to fill the void” (p. 13). To borrow Robert M. Davis's words, "[m]adness, dreams, sanctity, clairvoyance: all are attempts to escape the gray world of nada, of entropy, of the round tower from which Oedipa awaits to be delivered" (1972: 374).

From this moment onwards, hers becomes a paradoxical search for an unreachable final revelation that will never come, as the novel ends with the protagonist settled back "to await the crying of the lot 49" (p. 127), and the only alternatives remaining are silence and apocalypse. Perhaps because of her apparent 
paranoia, perhaps due to her feeling of isolation once she has concluded that the world surrounding her is not fully understandable, the protagonist longs for the creation of an alternative world, and thinks "Shall I project a world?" (p. 56) to fill the existencial gap she feels immersed in. In metafictional terms, it seems that Pynchon tries to raise once again the necessity of blurring categorical taxonomies between fiction and reality, paranoia and antiparanoia, central and marginal, and advocates a reconceptualization of classical thought.

Although in Pynchon's bewilderingly complex novel Gravity's Rainbow we do no longer find a female heroine-protagonist, some of the multiple roles conferred to the female figures should also be pointed out, as they are self-consciously sustained upon mythical and psychoanalytical undertones. Considering that the motif of the whole novel is the threat of an Armageddon, the female figure comes to represent at times a metaphorical refuge -the protective-mother role- amidst an alienating external world. The critic Robert A. Hipkiss (1984:15) remarks that "the overall delineation is that of the decadent White Anglo-Saxon Protestant, unsure of himself sexually, addicted to material comforts, ulcerous, revering youth, wanting knowledge and fearful of death." By the same token, one of the secondary characters, Franz Pökler, fills his "emptiness, fear, existential vacuum" (Pynchon, 1975: 407) with the moral strength that his wife Leni and daughter Ilse transmit to him so that he can survive in a world constantly menaced by the lethal V2.

Likewise, Slothrop, the protagonist of the novel, overcomes his feeling of isolation through several sexual affairs. But paradoxically, the narrative also employs the female interpretation of the protagonist's words when he metaphorically explains to Katje the trajectory of the lethal rocket striking its target. To the young woman, Slothrop's explanations about the rocket's ascent and descent towards its target remind her of a sexual relationship:

Ascending, programmed in a ritual of love [...] at Brennschluss it is done-the Rocket's purely feminine counterpart, the zero point at the center of its target, has submitted. All the rest will happen according to laws of ballistics. The Rocket is helpless in it. Something else has taken over. Something beyond what was designed in. (p. 223)

At other times, the use of opposing male/female couples is used in the narrative to establish clear distinctions between the taxonomic postulates of classical science on the one hand, and modern scientific theories supporting the indeterministic and random as inherent characteristics in nature, on the other. This is the case, for instance, of Roger Mexico, a male representative of the ideas of the new science in the novel, who tries to explain to his companion Jessica the V-bomb's reversal of the classical law of cause-and-effect: "a rocket will hit before people can hear it coming" (p. 54). A similar example is that of Franz and Leni. Franz, the "cause/effect man" (p. 159), is indoctrinated by his wife about the necessity to accept the realm of probabilities, thus 
questioning his categorical principles put forward by classical science: "Not produce," she tried, "not cause. It all goes along together. Parallel, not series. Metaphor. Signs and symptoms. Mapping on to different coordinate systems, I don't know” (p. 159).

Jungian theories can also offer a further approach to the ambiguous portrayals of some female characters in this novel. As also happened with V., Katje's figure oscillates between absence and presence, human and machine. Particularly remarkable is Slothrop's and Katje's love relationship. The narrative provides the reader with significant descriptive fragments of the female character featured by a psychoanalytical tinge; or to be more precise, by the Jungian concept of the anima -the feminine part of the unconscious. In some passages the narrative voice echoes the Jungian assimilation of the shadow archetype (Jung, 1971; Stark, 1980), the latter considered as a "dark" or instinctual unknown side of the personality that must be necessarily assimilated by the self for the fulfillment of an integrative identity. Slothrop, for example, feels that "there is still a dark side, her neutral side, her face, that he can no longer see, a terrible beastlike change" (p. 196) that he fears to face. At other times, for instance, Katje is described -suggesting an intertextual reference to the mysterious V.- just as if she were an inanimate object devoid of any human quality:

[...] the terrible Face That Is No Face, gone too abstract, unreadable: the notch of eye socket, but never the labile eye, only the anonymous curve of cheek, convexity of mouth, a noseless mask of the Other Order of Being, of Katjie's being, -the lifeless nonface that is the only face of hers he really knows, or will ever remember. (p. 222)

It seems, none the less, that Pynchon's social commitment places special emphasis on the fight of the solitary male struggling against the progressive dehumanization of modern life both in the sociopolitical and cultural spheres. We may think that the American author, echoing myth theories, wants to express his hope in a moment of synthesis which may abolish any conventionally established duality: male and female, mind and body, war and peace, gravity and rainbow. From epistemological premises, the blurring of ideological dualities accounts for the junction between objective and subjective knowledge, empirical determinism and paradoxical uncertainty. With transcendence, opposing principles are and become one single mandalic unity in a harmonious integration. Myth, in Pynchon's view, is necessary to overcome classical taxonomical dichotomies; it is even more needful "to survive the terrible antinomies which are the mental climate of this century", concludes Frank D. McConnell (1977: xxix).

Pynchon's complexity in the portrayal of female characterization and symbology is, in my opinion, best exploited in Vineland, where the symbolism of woman becomes self-consciously overt. A father, Zoyd, and his daughter, Prairie, start a new Pynchonean search, this time for their absent wife and mother Frenesi Gates. And it is precisely such absent female presence which turns out to be the real heroine of the 
novel. In fact, through Frenesi's eyes the narrative voice unveils a minute social, political, cultural, and ethical criticism of contemporary life in the U.S.

Like Oedipa in Lot 49, Frenesi Gates becomes the narratorial tool to describe the social conditions of the excessively technified and consumerist 20th-century America. By means of Frenesi, the writer introduces a symbolical tension between the fictional and the historical. In stark contrast with the 1980s Reaganite era, the female figure represents the social change initiated in the counter-cultural 1960s. As her name suggests, she represents the "gate" towards a better way of living than the present one. As an alternative to the society of the 1980s Frenesi reifies the ideas of pacifism, bohemian life, sexual liberty and justice. Broadly speaking, a world free from the chains of bourgeois politics and capitalist values. She is, like Oedipa, the advocate of the dishinherited, of the outlaws from the capitalist regime. As she herself explains, it is "the freedom granted to a few, to act outside warrants and charters, to ignore history and the dead, to imagine no future, no yet-to-be-born, to be able simply to go on defining moments only, purely, by the action that filled them" (Pynchon, 1990: 71-72).

Carefully detailed is the story of her own life, displayed in the novel as a constant quest to fight against patriarchal values while seeking to reinscribe the role of woman in contemporary society. Not by chance does the narrative voice state that, instead of being the conventional mother-wife, she works as a filmaker preferring her job to her family. And precisely through the lens of her camera she becomes the female focaliser of important historical details -literally, the "legendary observerparticipant from those times" (p. 51). But ironically, despite being the advocate of the marginal culture -the revolutionary counterculture- Frenesi, the stereotypical girl "with the old-fashioned hair and make up, always wearing either miniskirts or those weird-looking bell-bottoms they had back then" (p. 114), is trapped by the forces of the dominating power. She falls in love with FBI agent Brock Vond, who traps her into fighting back the social counterforce that she herself leads.

For the female protagonist, the modern world is described as an enormous cybernetic system made up of binary digits, of computer files that seem to have replaced individual human beings. With implicit harsh social criticism, it seems to her that there is no longer human existence but rather "electronic presence or absence" (p. 90). Whereas the spirit of the 1960s claimed, in Frenesi's own words, "a world of simplicity and certainty no acidhead, no revolutionary anarchist would ever find, a world based on the one and zero of life and death. Minimal, beautiful" (p. 72), the narrator's account offers the readers a harsh retrospective view of America's real history:

The injustices she had seen in the streets and fields, so many, too many times gone unanswered-she began to see them more directly, not as world history or anything too theoretical, but as humans, usually male, living here on the planet, often well within reach, committing these crimes, major and petty, one by one against other living humans. Maybe we all had to submit to History, she figured, maybe not -but 
refusing to take shit from some named and specified source- well, it might be a different story. (p. 80)

Apart from providing a harsh social criticism of contemporary US history, the complexity inherent in the female protagonist also allows the author to raise once again serious gnoseological questions, thus making Frenesi herself the emblem of the epistemological impossibility of ever reaching a satisfactory representation of external reality.

In Derridean terms, we can say that Frenesi is again a Pynchonean figure that becomes the literal materialisation of the 'absent presence' of the female. She is the signifier forever deferred, whose ultimate function is to "undermine the referential ground for linguistic functioning, setting the possible nonreferentiality of discourse against its potential referentiality in an undecidable opposition" (Solomon, 1988: 214). And precisely, the marginal, the always escaping figure of Frenesi is de facto the central element of the whole book.

In the first pages of the novel the narrative voice explains that Frenesi's file literally disappears from the FBI computer, textually forcing the reader to reconstruct her mysterious figure out of a series of multifarious semiotic representations. As a matter of fact, all the other characters of the novel are related to her, and all of them provide different details from the absent Frenesi. Her parents, Sasha and Hub give a detailed account of Frenesi's childhood and youth and suggest, for instance, that Frenesi's rejection to any form of militarism and domination was due to an excessive bombardment of parabellic propaganda and images on TV.

Further details about Frenesi are given by her ex-husband Zoyd, who recalls when they first met, their wedding day, her committment to freedom and justice; but particularly relevant is the role of Frenesi's daughter Prairie who, while in search of her mother, gathers a valuable number of data about the absent protagonist. Accompanied by the ninjette DL, a friend of Frenesi's, Prairie visits the Sisterhood of the Kunoichi Attentives, who happen to have a whole computer library with many documents -"legal history", "memoranda from the FBI", "shippings from underground papers", "transcripts from Frenesi's radio interviews". etc.- as well as some photographs and video tapes filmed by Frenesi and her group, The $24 \mathrm{fps}$. All this information is not only important to build up Frenesi's evanescent figure but also to lay bare the real historical events that Frenesi filmed during the decade of the sixties. All in all, some other secondary characters also look for Frenesi but each one for different reasons. Brock Vond, Frenesi's lover and FBI agent, Frenesi's present husband Flash and son Justin, or a paranoid TV addicted called Hector Zúñiga, who wants to make a film about the revolutionary sixties. Furthermore, the novel consciously adds more complexity to the entropic accumulation of data about the absent protagonist, and ironically tries to clarify Frenesi's fragmenting identity by including, in some short flashbacks, for instance, her pungeant words about injustices 
and repressions (p. 195) that the mass media do not transmit to society: "But to see injustices happening and ignore them, as your news team has been ignoring the repression of farm workers here in this county who've been trying to organize -that's more 'dangerous' in the long run, isn't it?" (p. 195), Frenesi says to her interviewer.

These are all complementary versions that, instead of providing a complete portrayal of the absent Frenesi, ultimately lead the reader towards the deferral of the female's 'real' signifier. At the end of the novel little Prairie wakes up and the reader is finally left at the blurred frontier between fantasy and reality -literally, "into the thin layer of waking dream" (p. 384). The female protagonist Frenesi Gates, the Derridean supplement with endless significations, thus reifies the impossibility of apprehending external reality in a satisfactory way. It seems, at least, that amidst such epistemological uncertainty the mythical undertones that underlie the novel suggest to the reader some hopeful escape from social injustice: "to harbor in Vineland, Vineland the Good" (p. 322).

The ambiguous 'absent presence' of the female is also remarkable in Pynchon's latest narrative creation, Mason \& Dixon, despite the male condition of the book's protagonists. Pynchon's fifth novel plays again with ambiguous self-intertextual echoes closely related to western female symbology and to the letter "v". In the first part of the novel the two commissioned surveyors and astronomers, Mason and Dixon, are in charge of an expedition "to observe the Transit of Venus" (p. 12). Later on, in their journey across America, their task is to open a "Visto" or line "in the true Parallel from the intersection of the North line from the Tangent Point with the parallel to the Ridge" (p. 682). Or, just to mention another intertextual cross-reference, chapter 8 describes a mother and her two daughters called the "Vrooms", who try to flirt with both astronomers.

As happened in previous novels, the blurring of frontiers between the factual and the imaginary becomes a recurrent motif in Pynchon's latest narrative. In metafictional terms, this novel insists on the tendency towards undifferentiation between the real and the fictional, both becoming now mere transcriptive versions of our interpretations of reality. In the case of the gothic Mason, he suffers from "Excess in Mourning" (Pynchon, 1997: 25) since his wife Rebekah died, and he holds some strange conversations with her apparitions. Mason's talks to the dead -and therefore absentRebekah represent a literal "wordless transgression of Cause and Effect" (p. 208), something that the astronomer, as a man of reason, can hardly believe. However, he finally seems to accept it despite his attachment to classical scientific principles: "He tries to joke with himself. Isn't this suppos'd to be the Age of Reason? [...]. But if Reason be also Permission at last to believe in the evidence of our Earthly Senses, then how can he not concede, to her some Ressurrection? -to deny her, how cruel!" (p. 164).

Most of Mason's and Rebekah's conversations take place at moments when the male protagonist needs to find some relief from the difficulties inherent in life. Echoing once again myth theory, a kind of integrative or transcendental essence is the 
one held by the dreamy female figure, whose main role is to help the desperate astronomer surmount his existential difficulties and even his epistemological angst. If for Mason his wife Rebekah metaphorically represented a secure harbour of refuge, now that he no longer has her, he feels lost in a difficult condition of despair and solitude:

Rebekah lost, my Anchor to all I knew of Birth and Death -I was adrift in Waters unknown, Intrigues and Factions within the Royal Society, as among Nations and Charter'd Companies. Foolishly seeking in the Alignment of Sun, Venus and Earth a moment redeem'd from the Impurity in which I must ever practice my Life [...] (p. 247)

Once the two astronomers start to question the validity of Newtonian reasoning to apprehend external reality, Rebekah significantly appears in a dream to her solitary husband and tries to explain his confusing thoughts about his own self. And so, the female figure - as if evoking Plato's world of shadows and its gnoseological implications- argues: "No need to feel pleas'd with yourself. What you found was not their sacred World, but only a Representation of it" (p. 725).

By the end of the novel the narrator announces that the absent-present Rebekah finally withdraws into silence. Mason melancholically longs for her presence, and he literally "prays to see her Face in the new Comet, -each night, this time, in terror of not seeing it" (p. 725). In a striking similarity with Slothrop's terrifying feeling of not being capable of apprehending Katje's face while they were making love in Gravity's Rainbow, Mason's melancholy deepens leading him to the point of not being able to "even remember her Face" (p. 725). It seems once again that we are (paradoxically?) contemplating the masculine need for the Jungian anima for the completion of the self. In philosophical terms, it could also be understood as the terror of feeling oneself alone amidst a world of uncertain conditions, which further explains the recurring mythical essence underlying the absent female presence in all Pynchon's novels. Female as a harbour of refuge, a mythical paradise for those lost creatures as Mason and Dixon "surrendering into a desire to transcend their differently discomforted lives" (p. 691).

As spokes(-wo)men of Pynchon's opinions, female characterisations are featured all along his literary works by an overt loss of confidence in the social and political panorama as well as in the everyday grasp of possibility and causality. On the one hand, the novels invalidate the absurd philosophy that rules the western world, mainly constructed upon taxonomic historical and cultural dichotomies. It is precisely through female focalizations that Pynchon has faithfully portrayed a thorough vision of the age of plastics, junkfood, film and TV, cybernetics, corruption, entropy and death; all in all, a world of absurd meaninglessness and physical disintegration. On the other hand, Pynchon shows a deep concern with postmodernism-rooted philosophical issues, and all his narratives insist that categorical thinking is no longer adequate to 
interpret modern life. His prose style is a magnificent compendium of signs -contradictory, polysemic, ambivalent, ambiguous. Interpretation is, in Pynchonean terms, always problematic and indefinite. And so, V., Oedipa, Frenesi or Rebekah advocate a refusal to accept the laws of the established world in all aspects of life.

But Pynchon's harsh portrayal of modern times does not necessarily mean the collapse of Western civilization and thought. Precisely, one of the main questions that the American author seems to posit is whether it is possible to devise alternative social, political, and economic arrangements to regenerate the modern wasteland. Within the context of postwar experimental fiction, J. Hendin further explains, Pynchon's fiction "offers an acceptance of dislocation as a major part of life and perhaps a hope that the displacement of traditional ideas might permit new ways of dealing with the human situation" (in Hoffman, 1979: 240).

We have seen that all the narratives have insisted, at a textual level, on the need to conciliate opposites in order to avoid the dangerous dichotomies that are still in control of modern history. Deeply sustained by the minute characterization of the female, the self-conscious dominant of Pynchon's novels invites their readers to withdraw from any categorical representation of reality, just as all his heroines decide to mediate the contradictions of culture: rich and poor, central and marginal, male and female. Acknowledging the uncertainty inherent to human existence and despite feeling prisoners of circumstances, Pynchon's female characters always aim at finding the means of regeneration.

Myth theorists as Eliade (1965) or Campbell (1968) explain that whereas life leads to death (and entropy), a mythical viewpoint accepts a renewal of life, a cyclic time process of decay and reconstruction. As shown insistently all along his literary career, Pynchon's dichotomies progress dialectically towards a reconciling moment, a final synthesis: both man and woman, order and chaos, fiction and history, the real and the imaginary. Only such a synthesis represents a potential source for further development: "a renewed quest, a beginning again on the one great spiritual journey of [wo]man to higher forms of life", Ted K. Spivey (1980: 81) quotes. It is the bringing down into the social arena of this mythical ideal integration what constitutes, in my reading of his oeuvre, one of Pynchon's deepest concerns as a social writer.

\section{References}

Adams, Henry, 1979 (1900). "The Dynamo and the Virgin", in The Education of Henry Adams, In BAIM, Nina et al. eds. Norton Anthology of American Literature (2nd. edition), vol. 2. New York: Norton.

Bock, Hedwig and Wertheim, Albert. eds. 1986. Essays on the Contemporary American Literature. München: Max Hueberg Verlag. 
Campbell, Joseph. 1979 (1968). The Hero with a Thousand Faces. Princeton: Princeton University Press.

Clerc, Charles. 1982. Approaches to “Gravity's Rainbow.” Columbus: Ohio State University Press.

CoOPER, Peter L. 1983. Signs and Symptoms: Thomas Pynchon and the Contemporary World. Berkeley, Los Angeles, London: University of California Press.

Cowart, David. 1980. Thomas Pynchon. The Art of Allusion. Carbondale: Southern Illinois University Press.

Davis, Robert M. 1972. "Parody, Paranoia, and the Dead End of Language in The Crying of Lot 49." Genre, vol. V (december), num. 4, pp. 367-277.

Eliade, Mircea. 1965. Rites and Symbols of Initiation: The Mysteries of Birth and Rebirth. New York: Harper and Row.

HaYles, N. Katherine ed. 1991. Chaos and Order. Complex Dynamics in Literature and Science. Chicago and London: The University of Chicago Press.

HenKLE, Roger B. 1971. "Pynchon's tapestries on the Western Wall." Modern Fiction Studies 17, 2, pp. 207-220.

HIPKISS, Robert A. 1984. The American Absurd. Pynchon, Vonnegut and Barth. Port Washington; N.Y.: Associated Faculty Press, Inc.

Hoffman, Daniel G., ed. 1979. Harvard Guide to Contemporary American Writing. Cambridge, Mass.: Harvard University Press.

JunG, Carl G. 1971 (1954) "Archetypes of the Collective Unconscious." In READ, Herbert et al. eds. The Collected Works. London: Routledge and Kegan Paul; vol. 9/1, pp. 3-53.

MacAdam, Alfred. 1975. "Pynchon as Satirist: To Write, To Mean". The Yale Review 67, pp. 555-566.

McConnell, Frank D. 1977. Four Postwar American Novelists: Bellow, Mailer, Barth, Pynchon. Chicago: University of Chicago Press.

McHale, Brian. 1979. "Modernist Reading, Post-Modern Text: The Case of Gravity's Rainbow.” Poetics Today I, 1-2, pp. 86-110.

McHoul, Alec \& WILLS, David, eds. 1990. Writing Pynchon: Strategies in Fictional Analysis. Urbana \& Chicago: University of Illinois Press.

NAdEAU, Robert. 1981. Readings from the New Book on Nature: Physics and Metaphysics in the Modern Novel. Armherst: the University of Massachusetts Press.

Newman, Robert D. 1983. "The White Goddess Restored: Affirmation in Pynchon's V." University of Mississippi Studies in English 4, pp. 178-186.

PEARCE, Richard. ed. 1981. Critical Essays on Thomas Pynchon. Boston, Massachusetts: G.K. Hall \& Co.

Plater, William M. 1978. The Grim Phoenix. Reconstructing Thomas Pynchon. Bloomington \& London: Indiana University Press.

Pynchon, Thomas. 1975 (1966). V. London: Picador. 
Pynchon, Thomas. 1979 (1967). The Crying of Lot 49. London: Picador.

Pynchon, Thomas. 1975 (1973). Gravity's Rainbow. London: Picador.

Pynchon, Thomas. 1990. Vineland. London: Seger \& Warburg.

Pynchon, Thomas. 1997. Mason \& Dixon. London: Jonathan Cape.

SEED, David. 1981. "Order in Thomas Pynchon's Entropy.” Journal of Narrative Technique vol. II, number 2, pp. 135-153.

Solomon, J. Fisher. 1988. Discourse and Reference in the Nuclear Age. Norman \& London: University of Oklahoma Press.

SpIVEY, Ted K. 1980. The Journey Beyond Tragedy. A Study of Myth in Modern Fiction. Florida: University Press of Florida.

StARK, John O. 1980. Pynchon's Fictions: Thomas Pynchon and the Literature of Information. Athens: Ohio University Press.

Stonehill, Brian. 1988. The Self-Conscious Novel: Artifice in Fiction from Joyce to Pynchon. Philadelphia: University of Pennsylvania Press.

TANner, Tony. 1979. City of Words. American Fiction 1950-1970. London: Jonathan Cape Ltd.

TAnNer, Tony. 1982. Thomas Pynchon. London: Methuen \& Co. Ltd. 